\title{
CHARACTER DISCOURSE BETWEEN STUDENTS AND SCHOOL TEACHERS IN YOGYAKARTA SPECIAL PROVINCE IN INDONESIA
}

\author{
Slamet Suyanto \\ Faculty of Mathematics and Natural Science Yogyakarta State University \\ email: slametsuyanto@yahoo.com
}

\begin{abstract}
A bstract: One of the critical points in character education in schools is the perception of good and bad characters between students and teachers. If there is a discourse on the perception, then there will be misleading on the character building in the classroom. The students who perceive that they do have good attitudes and perform good characters might be judged by the teacher as bad students. On the contrary, the teachers who believe that they have good attitudes and perform good characters might be considered by the students as disliked teachers. This survey research was conducted in 6 middle schools in Yogyakarta Special Province, involving 120 students and 120 teachers. The instrument of the research was mainly questionnaires consisting of three main groups of characters, namely performance, attitude, and behavior. Data were analyzed descriptively using a percentage. Inter-rater agreement analysis was administered to know the character admiration and discourse. The results indicate that there are some discourses between the students and the teachers on the behaviors, performance, and attitudes.
\end{abstract}

Keywords: character education, character discourse, character admiration

\section{WACANA KARAKTER ANTARA SISWA DAN GURU SEKOLAH DI DAERAH ISTIMEWA YOGYAKARTA INDONESIA}

\begin{abstract}
A bstrak: Salah satu poin penting dalam pendidikan karakter di sekolah adalah persepsi karakter baik dan buruk antara siswa dan guru. Jika ada wacana tentang persepsi, maka akan ada menyesatkan pada pembangunan karakter di dalam kelas. Para siswa yang merasa bahwa mereka memiliki sikap yang baik dan melakukan karakter yang baik mungkin akan dinilai oleh guru sebagai siswa yang buruk. Sebaliknya, para guru yang percaya bahwa mereka memiliki sikap yang baik dan melakukan karakter yang baik mungkin dianggap sebagai siswa yang tidak baik oleh guru. Penelitian survei ini dilakukan di 6 sekolah menengah di Provinsi Daerah Istimewa Yogyakarta yang melibatkan 120 siswa dan 120 guru. Instrumen penelitian ini terutama kuesioner yang terdiri atas tiga kelompok utama karakter, yaitu kinerja, sikap, dan perilaku. Data dianalisis secara deskriptif dengan menggunakan persentase. Analisis perjanjian antarpenilai diberikan untuk mengetahui kekaguman karakter dan wacana. Hasil penelitian menunjukkan bahwa ada beberapa wacana antara siswa dan guru pada perilaku, kinerja, dan sikap.
\end{abstract}

Kata K unci: pendidikan karakter, wacana karakter, kekaguman karakter

\section{RATIONALE}

Indonesian schooling faces many youth problemsand needs solutions urgentIy. According to the $\mathrm{N}$ ational Drug Bureau (BN N ), 50-60\% drug abusers are youth with the total of 3.8 to 4.2 million teenagers/ year (BN N, 2014). According to Sexual Behavior Survey (2011), sponsored by Fiesta condom factory, on 663 respondents, $64 \%$ of middle school students ages 15-19 watched adult videos and $39 \%$ of them experience sexual relationships. Base line survey done by BKKBN (2011) showed that there were about 2.4 million cases of abortion per year and $21 \%$ of them (700.000-800.000) were conducted by teenagers. A nother problem of youth delinquency is bullying. Data from Children Human Right 
(Komnas A nak, 2011) show that in 2011 there were 339 cases of bullying causing 82 people to die. In the first semester of 2012, there were about 139 cases of bullying with 12 deaths (Anonim, 2014). It is concluded that many school students have problems with drugs, sex, and bullying and solutions are imperative.

The same social problems are also experienced by American schools, e.g. racism, teen violence, teen pregnancy, low self-esteem, sexually transmitted diseases, drug and alcohol abuse, lying, stealing, and cheating (Jones et al, 1999; Josephson Institute of Ethics, 2006). According to the Ethics of American Youth survey, $82 \%$ of the students lied to their parents, $62 \%$ lied to their teachers, 33\% copied an internet document, $60 \%$ cheated in schools, $23 \%$ stole from parent, and $28 \%$ stole from store (Josephson Institute of Ethics, 2006).

The socio-emotional problems of youth that the schools encountered need solutions since those young people would be our next generation to lead the country in the future. Josephson (2012), the Director of Joshepson Institute of Ethics, anounced good news inferred from the last survey that the number of social problems decreased after the implementation of character education. This finding gives an enlightenment to the problem solution of the youth. Education and schooling are considered the most sistemic and powerful way to educate our young generation spe cifically by promoting character education. In the past, Indonesian educational system had several subjects related to character education including Idology Education (Pancasila), Civic Education (PKn), and Religion Education (Pendidikan Agama) that were designated to play important roles in character building to promote civilized society. The problem, however, the three subjects would unlikely be strong enough to cope with the increasing youth problems. Therefore, it is imperative to all teachers, no matter what the subjects are, to work together promoting character education in schools.

Character education in school has many facets, both in theoretical and practical bases. Cunningham et al. (2001) define character education as the way of schools to promote good habits of mind, heart, and action. This definition resembles the idea of the founding father of Indonesian education Ki Hadjar Dewantara who asserted that schools must develop rasa (feeling), raga (body) and karsa (willingness to act). Quoting Ralph Waldo Emerson, Lickona (2004:4) agrees that "Character is higher than intellect". Lickona identifies "Ten essential virtues" such as wisdom, justice, fortitude, love, positive attitudes, hardwork, integrity, gratitude, and humility (pp.8-11). Character Count (2009) states six pillars of character education, namely (1) trustworthiness; (2) respect; (3) responsebility; (4) fairness; (5) caring, and (6) citizenship. Murphy (1998:22) makes almost the same claim that the character education is based on ethical values rooted in a democratic society, as follow.

"According to the Declaration, effective character education is based on core ethical values rooted in democratic society, in particular, respect, responsibility, trustworthiness, justice and fairness, caring, and civic virtue and citizenship." (p. 22).

Craig (2007) notes three conceptions of character in public schools; those are (1) normative; (2) descriptive; and (3) shared characters. Normative character is the extension of those characters in the society. Descriptive character is non-normative character promoted by the school. The shared character is transactional; it is shared by the schools and the students. The shared cha- 
racter views character as a negotiable value or habit rather than the uniform clothes that all students must wear. In this type, even though the teacher serves as a role model, as it is proposed by Lumpkin (2008), students may not follow the teacher directly if the role model is not accepted by the students.

Character Education Partnership (CEP) (2010) lists eleven principles of character education praxis in schools. Among those are (1) the school defines "character" comprehensively to include thinking, feeling, and doing; (2) the school uses a comprehensive, intentional, and proactive approach to character development; and (3) the school staff is an ethical learning community that shares responsibility for character education and adheres to the same core values that guide the students. Many schools practice them; they define good characters, socialize, and teach them to the students, or even the staff model those characters. However, those principles do not always work as it is proposed. De Roche (2009) states the background condition for nurturing the characters: "Therefore character education is not about simply acquiring a set of behaviors. It is about developing the habits of mind, heart, and action that enable a person to flourish." (h.1). The question is how to develop those habits.

Every student, as a human being, has a right to choose the heart, the mind, and the habits of their characters. All human beings are born free and equal in dignity and rights (UN, 2010). Emanuel Kant, and later Renouvier, expected religious morality in education (Stock-Morton, 1988:107). August Comte, on the other hand, viewed the moral growth and development of students as a more modern and scientific principle, separated from that of staunch reli- gious instruction (p.122) (Michael Wat, 2011). In Indonesia, the development of character education rely upon their religion, ideology, society, and individuals. In relation to character development, students have a right to choose what and who they are re gardless of the religion, ideology, and society. Therefore, the students' choices are the core issue in character education. Schools and teachers must understand what character the students choose and perceive that they want to be. Schools and teachers cannot define good characters just from their perspective without considering students' perspective. This research figures out the perspective of both students and teachers relating to good character. The results of this research will hopefully give more understanding between teachers and students on students' perspectives and teachers' perspectives of good characters and bad characters.

Every student comes to school bringing a facet of characters learned from their home, i.e. from their parents, religions, friends, physical and social environments. Students bring their own beliefs and ideas into the formal learning situation. On the other hand, the teachers and schools may have desired characters different from the students. Thismay arise conflict on the character development in the school program. Students may respond in a negative way to the characters developed in the schools. According to Craig, "Objects of learning" can be differentiated according to context. They may be "intended", "enacted" or "lived". Students do not always learn what is intended. The teacher may enact an "object of learning" in a lesson that does not express the "intended object of learning" before the lesson, and a student may encounter an "object of learning" as a lived experience that was not intended or enacted 
by the teacher (Craig, 2007) Therefore, teachers must undertand the characters of their students and how to fit them to the character nurtured by the schools.

The problems of this research are: (1) What are the characters of good and bad teachers according to students? (2) What are the characters of good and bad students according to teachers? and (3) Do the students and the teachers have the same perception on good and bad characters or do they have characters discourse? The objectives of the research are: (1) to identify good and bad characters of teachers from the perspectives of students; (2) to identify good and bad characters of students from the perspectives of teachers; and (3) to know characters discourse between the students and the teachers.

\section{METHOD}

This survey research was conducted in Yogyakarta Special Province, Indonesia, involving 6 middle schools with 120 students and 120 teachers. The samples were taken purposively from the category of good, middle, and less favorite schools, from urban and rural areas. The characters identified included behaviors, performance, and moral. The samples were changed. Firstly, it was intended just for biology teachers, but then, the number of biology teachers in each school is limited to three or less. Therefore, it was changed to all teachers.

In this study, the teachers were asked to list ten best students and ten worst students according their judgment of their school. They also were asked to write the reason they chose them as good and bad students. On the other hand, the ten best and worst students were asked to write ten good teachers and ten bad teachers. They were also asked to write their reason why they choose them as good and bad teachers.

Table 1. The D ata Colection M odel

\begin{tabular}{lcc}
\hline & Good teacher & Bad teacher \\
\hline $\begin{array}{l}\text { Good } \\
\text { student }\end{array}$ & Characters & Characters \\
$\begin{array}{l}\text { Bad } \\
\text { student }\end{array}$ & Characters & Characters \\
\hline
\end{tabular}

Data Analysis was using a descriptive statistics in the form of percentage. The SPSS 18.0 version was also administered to measure the inter-rater agreement level on the characters $\left(r_{x y}\right)$. The characters with $r_{x y}$ $\geq 0.7$ is considered to have high agreement and thus considered agreed by the respondents.

\section{RESULTS AND DISCUSSION Results}

The results were organized into five variables as follow.

\section{Good Teachers According to G ood and Bad Students}

Students' perceptions on good and bad teachers are different on their characters. Good teachers according to good students should be smart, easily understood, joyful, and golden-hearted. However, according to bad students, good teachers are golden-hearted, joyful, good mark-giver, and temperless. The complete characters of good teachers according good and bad students are listed in Table 1.

\section{Good Students According to Good and Bad Teachers}

The characters of good students are slightly different from the perspective of good and bad teachers. The characters of good students according to good teachers are being smart, disciplined, respectful, 
and honest. While those according to bad teachers indude the characters of disciplined, respectfull, honest, and hardworking. The characters of good students according to good teachers are listed in Table 2 .

\section{The Characters of Bad Teachers}

The characters of bad teachers are also different from good and bad students.
A ccording to good students, among the cha racters of bad teachers are not smart, difficult to be understood, and impassionate. On thecontrary, the characters of bad teachers according to bad students indude being difficulttobeunderstood, impassionate, and getting angry easily. The complete characters of bad teachers are presented in Table 3.

Table 1. Characters of G ood Teacher A ccording to G ood and Bad Students

\begin{tabular}{|c|c|c|c|c|}
\hline Characters of good teachers & Good students & $\%$ & Bad students & $\%$ \\
\hline a. Smart & 32 & 26.67 & 12 & 10.00 \\
\hline b. Easily understood & 20 & 16.67 & 11 & 9.17 \\
\hline C. Joyful & 20 & 16.67 & 20 & 16.67 \\
\hline d. Golden-hearted & 15 & 12.50 & 28 & 23.33 \\
\hline e. Caring & 9 & 7.50 & 2 & 1.67 \\
\hline f. Respectful & 9 & 7.50 & 2 & 1.67 \\
\hline g. Fair & 6 & 5.00 & 2 & 1.67 \\
\hline h. Afectionate & 4 & 3.33 & 1 & 0.83 \\
\hline i. Helpful & 2 & 1.67 & 6 & 5.00 \\
\hline j. Temperless & 1 & 0.83 & 15 & 12.50 \\
\hline k. Wise & 1 & 0.83 & 6 & 5.00 \\
\hline I. Good Mark-giver & 1 & 0.83 & 15 & 12.50 \\
\hline Total & 120 & 100.00 & 120 & 100.00 \\
\hline
\end{tabular}

Table 2. The Characters of G ood Students A ccording to G ood and Bad Teachers

\begin{tabular}{llrrrr}
\hline $\begin{array}{c}\text { Characters Of Good } \\
\text { Students }\end{array}$ & \multicolumn{2}{c}{$\begin{array}{c}\text { Good } \\
\text { Teachers }\end{array}$} & \multicolumn{1}{c}{$\%$} & Bad Teachers & \multicolumn{1}{c}{$\%$} \\
\hline a. Smart & 32 & 26,67 & 10 & 8,33 \\
b. Disciplined & 27 & 22,50 & 30 & 25,00 \\
c. Respectful & 20 & 16,67 & 25 & 20,83 \\
d. Honest & 15 & 12,50 & 21 & 14,17 \\
e. Active & 7 & 5,83 & 8 & 6,67 \\
f. Hardworking & 6 & 5,00 & 17 & 14,17 \\
g. Perserverance & 4 & 3,33 & 2 & 1,67 \\
h. Dilligent & 4 & 3,33 & 1 & 0,83 \\
i. Responsible & 3 & 2,50 & 2 & 1,67 \\
j. Neat & 1 & 0,83 & 3 & 2,50 \\
k. Modest & 1 & 0,83 & 1 & 0,83 \\
& 120 & 100,00 & 120 & 100 \\
\hline
\end{tabular}


Table 3. The Characters of Bad Teachers A ccording to G ood and Bad Students

\begin{tabular}{lrrrr}
\hline Characters of Bad Teacher & Good Students & $\%$ & Bad students & $\%$ \\
\hline $\begin{array}{l}\text { 1. N ot smart } \\
\text { 2. Difficult to be }\end{array}$ & 35 & 29,17 & 9 & 7,5 \\
understood & 28 & 23,33 & 33 & 27,50 \\
$\begin{array}{l}\text { 3. Impassionate } \\
\text { 4. Getting angry easily }\end{array}$ & 15 & 12,50 & 30 & 25,00 \\
5. A bsent frequently & 10 & 8,33 & 25 & 20,83 \\
6. Non-IT users & 10 & 8,33 & 4 & 3,33 \\
7. Too many assignments & 8 & 6,67 & 4 & 3,33 \\
8. Irrelevant story tellers & 4 & 3,33 & 9 & 7,50 \\
9. Impolite, harse & 4 & 3,33 & 1 & 0,83 \\
10. Unfair & 3 & 2,50 & 3 & 2,50 \\
11. Untidy & 2 & 1,67 & 1 & 0,83 \\
& 1 & 0,83 & 1 & 0,83 \\
& 120 & 100 & 120 & 100 \\
\hline
\end{tabular}

Table 4. The Characters of Bad Students A ccording to G ood and Bad Teachers Good

\begin{tabular}{lrrrr}
\multicolumn{1}{c}{ Characters of Bad students } & Teachers & $\%$ & Bad Teachers & $\%$ \\
\hline 1. N ot smart & 25 & 20,83 & 14 & 11,67 \\
2. Lazy to do assigment & 25 & 20,83 & 27 & 22,50 \\
3. A bsent or out of school & 15 & 12,50 & 26 & 21,67 \\
4. Cheaters & 14 & 11,67 & 13 & 10,83 \\
5. Talking too much & 12 & 10,00 & 20 & 16,67 \\
6. Disrepectful, impolite & 9 & 7,50 & 7 & 5,83 \\
7. Passive & 8 & 6,67 & 6 & 5,00 \\
8. Rude, bully & 5 & 4,17 & 3 & 2,50 \\
9. Irresponsible & 4 & 3,33 & 2 & 1,67 \\
10. Dependent & 2 & 1,67 & 1 & 0,83 \\
11. Unneat & 1 & 0,83 & 1 & 0,83 \\
& 120 & 100 & 120 & 100 \\
\hline
\end{tabular}

\section{The Characters of Bad Students}

Thecharacters of bad students according to good teachers and bad teachers are different as listed in the Table 4. According to good teachers, the characters of bad students include being not smart, lazy, absent frequently, and cheaters. While according to bad teachers, the characters of bad students are lazy, absent, talking too much, and not smart. Those are slightly different in the ranks of percentage, but they are common in the kinds of the characters. The complete characters of bad students are listed in Table 4.

\section{Character Discourse}

It can be inferred from the data pre sented above that there are some character discourseon good and bad teachers according to good and bad students. There are also some discourse on the character of good and bad students according too good and bad teachers. The complete data are presented on Table 5. 
Table 5. Character Discourse Between G ood Teachers and Bad Teachers

\begin{tabular}{|c|c|c|}
\hline & $\begin{array}{l}\text { Good } \\
\text { Students }\end{array}$ & Bad Students \\
\hline $\begin{array}{l}\text { Good } \\
\text { Teachers }\end{array}$ & $\begin{array}{l}\text { Smart } \\
\text { Easily } \\
\text { understood } \\
\text { Joyful }\end{array}$ & $\begin{array}{l}\text { Easily } \\
\text { understood } \\
\text { Golden-hearted } \\
\text { Joyful } \\
\text { Goodmark giver }\end{array}$ \\
\hline $\begin{array}{l}\text { Bad } \\
\text { Teachers }\end{array}$ & $\begin{array}{l}\text { Not smart } \\
\text { Difficult to be } \\
\text { understood } \\
\text { Impassionate } \\
\text { Getting angry } \\
\text { easily } \\
\text { A bsent } \\
\text { frequently }\end{array}$ & $\begin{array}{l}\text { Difficult to be } \\
\text { understood } \\
\text { Impassionate } \\
\text { tting angry easily } \\
\text { Givinf too many } \\
\text { assignments } \\
\text { Not smart }\end{array}$ \\
\hline
\end{tabular}

Table 6. Character Discourse Good Students and Bad Students

\begin{tabular}{lll}
\hline & Good teachers & Bad teachers \\
\hline Good & Smart & Disciplined \\
students & Disciplined \\
Respectful & Respectful \\
Honest & $\begin{array}{l}\text { Honest } \\
\text { Active } \\
\text { Hardworking }\end{array}$ \\
Bad & Not smart & Lazy to do \\
students & Lazy to do & assigment \\
& assigment & A bsent \\
& Absent or out of & Talking too \\
school & much \\
& Cheaters & Cheaters \\
& Talking too much & Not smart \\
\hline
\end{tabular}

\section{Discussion}

\section{Good Teachers}

The characters of good teachers according to good students are slightly different from those of bad students'. Good students consider "smart", as one of the most important characters of good teachers. This is a professional character of professional teachers. According to UK standard of teacher quality, a teacher must "have a secure knowledge of the relevant subject(s) and curriculum areas, foster and maintain pupils' interest in the subject, and address misunderstandings." (Department for Edu- cation, 2015). Good students are mostly smart students and they like very much smart teachers. On the contrary, bad students put "goodmark giver" as a character of good teachers. This is reasonable since bad students mostly not smart, they like very much teachers that give them a good mark. According to the standard, good teachers uphold public trust in the profession and maintain high standards of ethics and behavior, within and outside school, by treating pupils with dignity, building relationships rooted in mutual respect. The influence of a teacher's expectations to the students' performance is critical, even before the student has had an opportunity to perform. The standard \# 1 says that teachers "Set high expectations which inspire, motivate and challenge pupils." Once in the classroom, a teacher's expectations may be further shaped by the students' abilities such as following instructions, work habits, motivation, and behavioral compliance(Brophy \& Good, 1974; Janes, 1996; Jussim \& Eccles, 1992; Rosenthal \& Jacobson, 1968).

\section{Bad Teachers}

Bad teachers acorrding to good students are "not smart", "difficult to be understood", "impassionate", "getting angry easily", and "absent frequently". The character "not smart" as a character of bad teachers is in reverse to the "smart" as the character of good teachers. Those characters are slightly different from those of bad students who put "too many assignments" as one of the characters of bad teachers. Bad students mostly have a character of "lazy to do assignment", therefore they hate assignment and homework. In this case, teachers' normative expectations have an effect on students' certified learning and these normative expectations can be influenced by perceptual biases (Jussim \& 
Eccles, 1992). In addition, the more rigid these teacher's expectations are, the less they are subject to change (Clifton, Perry, Parsonson, \& Hryniuk, 1986; Kolb \& Jussim, 1994). The effects of teachers' normative expectations will have negative implications for students of racial and ethnic minorities if teachers' perceptions of students are based on arbitrary factors.

It is interesting from this study that some teachers score zero. These teachers get the same vote both as good teachers and as bad teachers. They get vote as good teachers from good students and get bad vote from bad students at the same number. In this case, these teachers may be good for teaching good students, but not fitting enough to teaching bad students.

\section{G ood Students}

There is a different perception on "good students" betweengood teachers and bad teachers. According to good teachers, good students have characters of being "smart", "disciplined", "respectful", and "honest". Meanwhile, bad teachers rank "disciplined", "respectful", "honest", "active" and "hardworking" as good students' characters. This finding resembles the prior study revealing that the preservice teachers who were told to pay attention to the students' prior educational achievement when making recommendations about student placement did exactly as they were told (Riley and Ungerleider, 2008). Teachers often bring their opinions about their good students to the office, and it becomes a trending topic among teachers to build their opinions on students. Sometimes this opinion affect a teacher's grading process.

\section{Bad Students}

Bad students according to good teachers are those who are "not smart", "lazy to do assigment", "absent or out of school" frequently, "cheaters", and "talking too much". Those characters are also agreed by bad teachers, except the order. The study done by Riley and Ungerleider (2008) revealed a tendency to rank ESL students lower than others. Some minority or disavantaged students may be ranked low by the teachers.

\section{Character Discourse}

This study revealed that there are some character discourse among good and bad students and among good and bad teachers. Good students like smart teacher, while bad students like very much teachers that easily give a good mark. Some studies point to the need for a study that would determine whether teachers' decisions about students are influenced by the students' ascribed characteristics. The meta-analysis of Pygmalion effects by Raudenbush (1984) indicated that "subjective impressions of people are more manipulable when previous information is ambiguous or missing" (A belson, 1995:152). In other words, if a teacher had prior contact with a student, the teacher would be more influenced by his or her interaction with the student than by abstract information. In addition, children may also get better or worse character because of their environment, not merely from school. Children cannot enter the educational system at age four and stay until age seventeen without having their character and moral values profoundly affected by the experience, for better or for worse. Further, becoming a serious student is one of the great ethical challenges the majority of our children face during their youth. In short, character education is inevitable, so we should be intentional about helping children to develop good habits (or virtues) and to struggle against bad ones 
(Bohlin, et al, 2011). A ccording to Character Education, the application of social-emotional and character development (SECD) in classrooms is about teaching, practicing, and modeling essential personal and civic life habits and skills that are almost universally understood as making people good human beings (Character Education, 2010: 47). Since the numberof children with behavioral problems and other attitude issues continues to be on the rise, Character Education is becoming a necessity (Brannon, 2008:59).

\section{CONCLUSION}

It can be concluded from this study that:

- There are some character differences of good and bad teachers and between good students and bad students.

- The characters of good teachers according to good students include being "smart", "easily understood", "joyful", and "golden-hearted". However, according to bad students the characters of good teachers are "golden-hearted", "joyful", "temperless", and "good markgiver".

- The characters of bad teachers according to good students and bad students are slightly different. According to good students, the characters of good teachers are "not smart", "difficult to be understood", and impassionate. According to bad students, the characters of bad teachers are "difficult to be understood", "impassionate", and "getting angry easily".

- The characters of good students according to good teachers and bad teachers are also slightly different. A ccording to good teachers, the characters of good students are being, "smart", respectful, and "honest". According to bad teach- ers, the characters of good students are "disciplined", "respectful", and "honest".

- The characters of bad students according to good teachers and bad teachers are also slightly different. According to good teachers, the characters of bad students are "not smart", "lazy", "absent frequently", and "cheating". According to bad teachers, the characters of bad students are are lazy, absent, talking too much, and not smart.

- There some character discourse, both among the students and among the teachers. Therefore, to minimize the discourse, the characters promoted in schools must be negotiated between teachers and students.

\section{WORDS OF GRATITUDE}

On this occasion, I would like to express millions of gratitude and thanks to junior and senior principals, teachers, and students who have been willingly involved in this research from whom the researcher has got data and meaning from their participations. I Hope this research would be beneficial to improve the characters of teachers and students.

\section{REFERENCES}

Anonim. 2014. Kriminalitas Remaja di Sekitar Kita. http:/ / syabab.com/ anak-muda/ buletin/ 2987-kriminalitas-remaja-di-sekitar-kita.html. Retrieved on January 3rd, 2015.

Benninga, Jacques S., Marvin W. Berkowitz, Phyllis Kuehn \& Karen Smith. 2003. "The Relationship of Character Education Implementation And Academic Achievement In Elementary Schools". Journal of Research in Character Education, 1(1), 2003, pp. 19-32. 
Bohlin, K. E., Farmer, D. L., Ryan, K., \& Ryan, K. 2001. Building Character in Schools Resource Guide. San Francisco: Jossey-Bass.

BKKBN. 2011. Fenomena Kenakalan Remaja di Indonesia. Jakarta: BKKBN.

BNN. 2014. Laporan A khir Survei Nasional Perkembangan Penyalahgunaan N arkoba Tahun Anggaran 2014. Jakarta: BN N.

Brannon, D. 2008. "Character Education - A Joint Responsibility". Education Digest, Vol. 73, No. 8, pp. 56-60. Retrieved From ERIC Database Character Education: Better Students, Better People. (2010). Education Digest, Vol. 75, No. 7, pp. 47-49.

Chapman, Alicia M. 2011. “Implementing Character Education into School Curriculum". ESSAI: Vol. 9, A rticle 11.

Colgan, C. 2003. “Making Character Education Work". American School Board Journal, Vol. 190, No. 11, pp. 34-35. Retrieved from A cademic Search Premier 15th February, 2015.

Cunningham, Craig A. 2007. Character Education in Public Schools: the Quest for a Suitable Ontology. National-Louis University.http:/ / cuip.uchicago.edu I - cac/ pubs.htm retrieved on June 23rd, 2008.

Davis, Michael. 2003. "What's Wrong with Character Education?" A merican Journal of Education, $V$ ol. 110 (2003), http:/ / www.journals.uchicago.edu/ cgi-bin/ resolve retrieved on August 21st, 2004.
DeRoche, Edward. 2009. The What, Why, and $\mathrm{H}$ ow of Character Education. http:/ / www.csee.org/ products/ 108 retrieved on May 7th, 2010.

Fertman, Carl \& Van Linden, Josephine A. 1999. "Character Education: An Essential Ingredient for Youth Leadership Development National Association of Secondary School Principals". NASSP Bulletin; Oct 1999; 83, 609; ProQuest.

Hamilton, Elizabeth L. 2010. Character E ducation that Excites Young Children! http:/ / ezineartides.com/ ?CharacterEducation-That-Excites-YoungChildren!\&id=3849623 retrieved on May 22nd, 2011.

Higgins, A. \& Alessandro. 2005. Character Education. http:/ / en.wikipedia.org/ w/ index.php?title=Character_educat ion\&oldid $=410411318$ retrieved on July 24th, 2006.

Jones, Emily N., Kevin Ryan, \& Karen Bohlin. 1999. "Character Education \& Teacher Education: How Are Prospective Teachers Being Prepared to Foster Good Character in Students?" Action in Teacher Education. Vol. 20, No. 4, 1999.

Jussim, L., \& Eccles, J. 1992. Teacher "Expectations 2: Construction and Reflection of Student Achievement". Journal of Personality and Social Psychology, Vol. 63, pp. 947-961.

Kant, Immanuel, and Mary J Gregor. 1998. Groundwork of the Metaphysics of M orals. Cambridge, U.K.: Cambridge University Press. 
Lickona, Thomas. 2004. Character M atters: How to Help Our Children Develop Good Judgement, Integrity and Other Essesntial Virtuoues. New York, NY: Touchstone.

Lickona, Thomas. \& Davidson, M. 2005. Smart \& Good High Schools: Integrating Excellence and Ethics for Success in School, Work, and Beyond.Courtland, NY: Center for the 4th and 5th Rs.

Lumpkin, Angela. 2008. "Teachers as Role Models Teaching Character and Moral Virtues". Journal of Physical Education, Recreation \& Dance; Feb 2008; Vol. 79, No. 2.

Murphy, M. 1998. Character Education in A merica's Blue Ribbon Schools. Lancaster, PA: Technomic Publishing.

Narvaez, Darcia, Vladimir Khmelkov, Enny L. Vaydich, \& Julianne C. Turner. 2008. "Measuring Teacher SelfEfficacy for Moral Education". Journal of Research in Character Education. Vol. 6, No. 2, 2008.
Riley, Tasha \& Charles Ungerleider. 2008. “Preservice Teachers' Discriminatory Judgments". TheA IbertaJ ournal of Educational Research, Vol. 54, No. 4, Winter 2008, 378-387.

The Ethics of American Youth. 2012. For the First Time in A D ecade, Lying, Cheating and Stealing A mong A merican Students D rops. http:/ / josephsoninstitute.org/ index.html retrieved July 18th, 2014.

Vardin, Patricia. 2008. Encouraging Good Character in Young Children. http:/ / www.edact.com/ blog/ ?p=36/ retrieved June 14th, 2013

Watz, Michael. 2011. "An Historical AnaIysis of Character Education". Journal of Inquiry \& Action in Education, Vol. 4, No. 2, 2011. 